\title{
Distribution of erm genes and low prevalence of inducible resistance to clindamycin among staphylococci isolates
}

Authors

Vivian de Lima Spode Coutinho $^{1}$

Rodrigo Minuto Paiva ${ }^{1}$ Keli Cristine Reiter ${ }^{1}$ Fernanda de-Paris ${ }^{1}$ Afonso Luis Barth ${ }^{1}$ Alice Beatriz Mombach Pinheiro Machado ${ }^{1}$

${ }^{1}$ Department of Microbiology and Molecular Biology,

Universidade Federal do Rio Grande do Sul.
Submitted on: $3 / 5 / 2010$ Approved on: 6/8/2010

\section{Correspondence to:}

Vivian de Lima Spode Coutinho

Rua Ramiro Barcelos, 2350, Porto Alegre - RS CEP: $90035-903$

Phone: +55 5133598860 Fax: +55 5133598310

E- mail:

viviandels@bol.com.br

This research was supported by FIPE.

We declare no conflict of interest.

\begin{abstract}
Introduction: Resistance to macrolides, lincosamides and streptogramins $\mathrm{B}\left(\mathrm{MLS}_{\mathrm{B}}\right.$ antibiotics) in staphylococci may be due to modification in ribosomal target methylase encoded by erm genes. The expression of $M_{L} S_{B}$ resistance lead to three phenotypes, namely constitutive resistance $\left(\mathrm{cMLS}_{\mathrm{B}}\right)$, inducible resistance $\left(\mathrm{iMLS}_{\mathrm{B}}\right)$, and resistance only to macrolides and streptogramins $\mathrm{B}\left(\mathrm{MS}_{\mathrm{B}}\right)$. The $\mathrm{iMLS}_{\mathrm{B}}$ resistance is the most difficult to detect in the clinical laboratory. Objective: This study investigated the expression of $M_{L} S_{B}$ resistance and the prevalence of the erm genes among 152 clinical isolates of Staphylococcus aureus and coagulase-negative Staphylococcus (CNS) from Hospital de Clínicas de Porto Alegre. Methods: Primary $\mathrm{MLS}_{\mathrm{B}}$ resistance was detected by the disk diffusion method. Isolates with iMLS $\mathrm{B}_{\mathrm{B}}$ phenotype were tested by double-disk induction method. All isolates were tested by a genotypic assay, PCR with specific primers. Results: A total of $46.7 \%$ of staphylococci were positive for $\mathrm{CMLS}_{\mathrm{B}} ; 3.3 \%$ for $\mathrm{iMLS}_{\mathrm{B}}$ and $3.3 \%$ for $\mathrm{MS}_{\mathrm{B}}$. One or more erm genes were present in $50.1 \%$ of isolates. The gene ermA was detected in 49 isolates, erm $\mathrm{C}$ in 29 and ermB in 3. Conclusion: The prevalence of the ermA, $\mathrm{ermB}$ and $\mathrm{erm} \mathrm{C}$ genes were $29.6 \%, 17.1 \%$ and $0.66 \%$ respectively, and constitutive resistance was the most frequent as compared to the other two phenotypes.
\end{abstract}

Keywords: Staphylococcus; resistance; erm genes; macrolides.

[Braz J Infect Dis 2010;14(6):564-568]@Elsevier Editora Ltda.

\section{INTRODUCTION}

Staphylococcus aureus and coagulase negative staphylococci (CNS) are recognized to be causing nosocomial and communityacquired infections worldwide. A great concern related to these microorganisms is their ability to develop resistance to antibiotics which originally were active against these species. ${ }^{1,2,3}$ Although $\beta$-lactam antibiotics are the main compounds used to treat infections due to staphylococci, macrolides, lincosamides e streptogramins type $\mathrm{B}\left(\mathrm{MLS}_{\mathrm{B}}\right)$ antibiotics are also widely used to treat staphylococcal infections. These antibiotics exert similar inhibitory effects on bacterial protein synthesis, but they are chemically distinct. ${ }^{4,5} \mathrm{MLS}_{\mathrm{B}}$ resistance can be caused by several mechanisms, but the predominant form is target modification mediated by erm $\mathrm{A}$, erm $\mathrm{B}$ e erm $\mathrm{C}$ (erythromycin ribosome methylase) genes. ${ }^{4,5}$ The erm genes encode enzymes that confer inducible or constitutive resistance to $M L S_{B}$ agents via methylation of the $23 \mathrm{~S} \mathrm{rRNA}$, thereby reducing binding by $\mathrm{MLS}_{\mathrm{B}}$ agents to the ribosome. ${ }^{6,7}$ Constitutive $\mathrm{MLS}_{\mathrm{B}}$ resistance can be detected by the disk diffusion test in laboratorial routine. ${ }^{8}$ Strains with constitutive $\mathrm{MLS}_{\mathrm{B}}$ resistance show high-level in vitro cross resistance among $\mathrm{MLS}_{\mathrm{B}}$ drugs. However, staphylococci isolates with inducible $\mathrm{MLS}_{\mathrm{B}}$ resistance demonstrate clear in vitro resistance to 14 and 15 -member macrolides (e.g., erythromycin), while they seem to be susceptible to 16 -member macrolides, lincosamides and streptogramins type B. Therefore, strains can show in vitro erythromycin resistance and false clindamycin susceptibility, because the conventional disk-diffusion may fail to detect inducible $\mathrm{MLS}_{\mathrm{B}}$ resistance. ${ }^{4,9,10}$ The Clinical and Laboratory Standards Institute (CLSI) developed a phenotypic method (the double-disk diffusion test (D test) to screen for inducible resistance. ${ }^{11}$ However, the polymerase chain 
reaction (PCR) with specific primers is a genotypic method used to confirm the presence of the $\mathrm{MLS}_{\mathrm{B}}$ genes, erm $\mathrm{A}$, erm $\mathrm{B}$ e erm $\mathrm{C} .{ }^{12}$ The risk for therapeutic failure is increased as constitutive resistance may raise from $\mathrm{iMLS}_{\mathrm{B}}$ during the course of clindamycin therapy in patients with severe staphylococci infections. ${ }^{11}$

The objective of this study was to determine the prevalence of the $\mathrm{MLS}_{\mathrm{B}}$ genes in Staphylococcus aureus and coagulase negative staphylococci from patients attending the Hospital de Clínicas de Porto Alegre (HCPA).

\section{MATERIALS AND METHODS}

\section{Bacterial isolates}

Isolates of $S$. aureus and of CNS were collected from consecutive clinical specimens sent to the of microbiology laboratory of the HCPA. The period of the study was between September and October 2007. The bacterial identification was performed through Gram's technique and catalase and coagulase tests. Isolates were stored in glycerol broth at $-20^{\circ} \mathrm{C}$ until use.

\section{Susceptibility tests}

The antimicrobial susceptibility test was performed by the disk diffusion method on Mueller Hinton Agar (bioMérieux, Marcy L'Etoile, France), according to the Clinical and Laboratory Standards Institute (CLSI 2008), with the following antibiotic (Oxoid $\left.{ }^{\circledR}\right)$ : oxacillin $(1 \mu \mathrm{g})$, cefoxitin $(30 \mu \mathrm{g})$, vancomycin $(30 \mu \mathrm{g})$, gentamicin $(10 \mu \mathrm{g})$, clindamycin $(2 \mu \mathrm{g})$, chloramphenicol $(30 \mu \mathrm{g})$, doxycycline $(30 \mu \mathrm{g})$, erythromycin $(15 \mu \mathrm{g})$, levofloxacin $(5 \mu \mathrm{g})$, rifampin $(5 \mu \mathrm{g})$ and trimethoprim-sulfamethoxazole $(25 \mu \mathrm{g})$. S. aureus ATCC 25923 was used for quality control.

The standard CLSI double-disk diffusion (D test) test was performed using Mueller Hinton agar (bioMérieux, Marcy L'Etoile, France) with a $15 \mu$ g erythromycin disk and $2 \mu \mathrm{g}$ clindamycin disk (Oxoid ${ }^{\circledR}$ ) placed at distances of 15 and $26 \mathrm{~mm}$ and incubated for $24 \mathrm{~h}$ at $35^{\circ} \mathrm{C} .{ }^{11}$
The inducible phenotype was characterized by a positive D test, a flattening of the inhibition zone around the clindamycin disk near to the erythromycin disk and indicates that erythromycin has induced clindamycin resistance $\left(\mathrm{iMLS}_{\mathrm{B}}\right)$. The phenotype $\mathrm{CMLS}_{\mathrm{B}}$ was characterized by erythromycin and clindamycin resistance. Finally, the phenotype $\left(\mathrm{MS}_{\mathrm{B}}\right)$ was characterized by clindamycin susceptibility and erythromycin resistance, with negative $\mathrm{D}$ test.

\section{erm $\mathrm{A}$, erm $\mathrm{B}$ and erm $\mathrm{C}$ gene detection}

A direct colony suspension of the culture equivalent to a 1.0 McFarland standard was prepared in $500 \mu \mathrm{L}$ of $10 \mathrm{mM}$ Tris-1 mM EDTA ( $\mathrm{pH} 8.0$ ), vortexed, and boiled for $10 \mathrm{~min}$ an aliquot of $5 \mu \mathrm{L}$ of the suspension was used for each $25 \mu \mathrm{lL}$ reaction mixture. ${ }^{13}$

PCR assays and primers specific from the erm $\mathrm{A}$ erm $\mathrm{B}$ and erm $\mathrm{C}$ resistance genes used in this study have been previously described by Gerard, Lina et al. (Table 1). ${ }^{14}$ Each reaction was carried out in a final volume of $25 \mu \mathrm{L}$ and included $10 \times$ PCR buffer $\left(\mathrm{pht}^{\circledR}\right) ; 3 \mathrm{mM}$ of $\mathrm{Mg}$ $\mathrm{Cl}_{2}$ (pht $\left.{ }^{\circledR}\right) ; 5 \mu \mathrm{M}$ of each ermA, ermB and erm $\mathrm{C}$ forward and reverse primers (Invitrogen ${ }^{\circledR}$ ); RNAse and DNAse free water; $1.25 \mathrm{U}$ of Taq DNA polymerase $\left(\mathrm{pht}^{\circledR}\right) ; 2.5 \mathrm{mM}$ of each dATP, dTTP, dCTP, and dGTP (ABgene $\left.{ }^{\circledR}\right)$; and $5 \mu \mathrm{L}$ of DNA. The PCR mixture was subjected to thermal cycle $\left(30\right.$ cycles of $30 \mathrm{~s}$ at $94^{\circ} \mathrm{C}$ as the denaturation step, $30 \mathrm{~s}$ at $57^{\circ} \mathrm{C}$ as the annealing step, and of $5 \mathrm{~min}$ at $72^{\circ} \mathrm{C}$ as the extension step) with a JMR ${ }^{\circledR}$ PTC-100. The PCRamplified reaction mixture was resolved by electrophoresis through a $2 \%$ agarose gel containing ethidium bromide in Tris-borate-EDTA buffer at $12 \mathrm{~V} / \mathrm{cm}$ for $30 \mathrm{~min}$. The gel was visualized under UV light and the sizes of the amplification products were estimated by comparison with 100 bp molecular size standard ladder.

Three clinical samples with positives results for each of the three genes were submitted to sequencing and analyzed by BLAST and Chromas and DDBJ/EMBL/ GenBank. These isolates were used as positive control in all experiments.

Table 1. Correlation between erm genes and MLSB resistance phenotypes

\begin{tabular}{|c|c|c|c|c|c|c|c|}
\hline \multirow[b]{2}{*}{ Isolate } & \multirow[b]{2}{*}{ Phenotype } & \multicolumn{6}{|c|}{ Genotype } \\
\hline & & ermA & ermB & ermC & $\begin{array}{c}\text { ermA/ } \\
\text { ermC }\end{array}$ & $\begin{array}{c}\text { ermA/ } \\
\text { ermB }\end{array}$ & $\begin{array}{c}\text { erm } \mathrm{A} / \text { erm } \mathrm{B} / \\
\text { erm } \mathrm{C}\end{array}$ \\
\hline \multirow{3}{*}{ S. aureus } & $40\left(\mathrm{cMLS}_{\mathrm{B}}\right)$ & 36 & 1 & 3 & 0 & 0 & 0 \\
\hline & $3\left(\mathrm{iMLS}_{\mathrm{B}}\right)$ & 2 & 0 & 1 & 0 & 0 & 0 \\
\hline & $2\left(\mathrm{MS}_{\mathrm{B}}\right)$ & 0 & 0 & 0 & 0 & 0 & 0 \\
\hline \multirow{3}{*}{ CNS } & $24\left(\mathrm{cMLS}_{\mathrm{B}}\right)$ & 0 & 0 & 20 & 2 & 1 & 1 \\
\hline & $2\left(\mathrm{iMLS}_{\mathrm{B}}\right)$ & 0 & 0 & 2 & 0 & 0 & 0 \\
\hline & $3\left(\mathrm{MS}_{\mathrm{B}}\right)$ & 0 & 0 & 0 & 0 & 0 & 0 \\
\hline
\end{tabular}




\section{RESULTS}

A total of 152 strains including 94 S. aureus and 58 CNS were included in this study. Eighty-one (53.3\%) exhibited erythromycin resistance and were considered for evaluation of the three distinct $\mathrm{MLS}_{\mathrm{B}}$ resistance phenotypes $\left(\mathrm{CMLS}_{\mathrm{B}}, \mathrm{iMLS}_{\mathrm{B}}\right.$, $\mathrm{MS}_{\mathrm{B}}$ ). Among these 81 erythromycin-resistant strains, 10 showed clindamycin susceptibly and were tested by doubledisk diffusion method. We found only five (6.2\%) isolates with $\mathrm{iMLS}_{\mathrm{B}}$ resistance phenotype (three $S$. aureus and two CNS) and five (6.2\%) with $\mathrm{MS}_{\mathrm{B}}$ resistance phenotype (two S. aureus and three CNS). The remaining 71 (87.7\%) isolates were considered as $\mathrm{CMLS}_{\mathrm{B}}$ resistance phenotype (46 S. aureus and $25 \mathrm{CNS}$ ).

All the 152 strains were tested for the presence of $\mathrm{MLS}_{\mathrm{B}}$ resistance genes and 77 (50.1\%) contained one or more erm genes (Figure 1). The ermA gene was detected in 44 isolates (41 S. aureus and three CNS), the ermB gene was found in only one isolate of $S$. aureus and the erm $\mathrm{C}$ gene was detected in 28 isolates (four S. aureus and $24 \mathrm{CNS}$ ). Combination of erm genes was detected in 4 CNS isolates (Graphics 1 and 2). For $S$. aureus isolates with $\mathrm{cMLS}_{\mathrm{B}}$ resistance phenotype, 36 presented the erm $\mathrm{A}$ gene, only one exhibited the erm $\mathrm{B}$ gene and three had the erm $\mathrm{C}$ gene. Moreover, in three of the $S$. aureus isolates with $\mathrm{iMLS}_{\mathrm{B}}$ resistance phenotype, two isolates were ermA positive and one was erm $\mathrm{C}$ positive. The erm $\mathrm{C}$ gene was identified in 20 isolates of CNS with $\mathrm{CMLS}_{\mathrm{B}}$ resistance phenotype and in two isolates of CNS with $\mathrm{iMLS}_{\mathrm{B}}$ resistance phenotype. Seven (six S. aureus and one CNS) isolates with $\mathrm{CMLS}_{\mathrm{B}}$ resistance phenotype did not present any of the three erm genes (Table 1). Resistance to non$\mathrm{MLS}_{\mathrm{B}}$ antibiotics in S. aureus and CNS isolates with erm genes was higher in relation to the isolates without the erm genes: chloramphenicol $(p=0.004)$, doxycycline $(p<0.001)$, gentamicin $(p<0.001)$, levofloxacin $(p<0.001)$, oxacillin $(\mathrm{p}<0.001)$, rifampin $(\mathrm{p}<0.001)$ and, trimethoprim-sulfamethoxazole ( $\mathrm{p}<0.001)$. Of the 77 isolates who harbored erm genes, 65 (40 S. aureus and 25 CNS) were multidrug resistant (resistant to five or more antimicrobial class). The overall range of multiresistance among the staphylococci strains studied was $48.2 \%$.

Figure 1:(A) Lanes 1 and 2 ermA positive in $421 \mathrm{bp}$; lane 3 negative control; lane 4 positive control; and lane $5100 \mathrm{bp}$ molecular size ladder. (B) Lane 1 ermB positive in $359 \mathrm{bp}$; lane 2 negative control; lane 3 positive control; and lane $4100 \mathrm{bp}$ molecular size ladder. (C) Lane 1 ermC positive in $572 \mathrm{bp}$; lane 2 negative control; lane 3 positive control; and lane 4100 bp molecular size ladder.
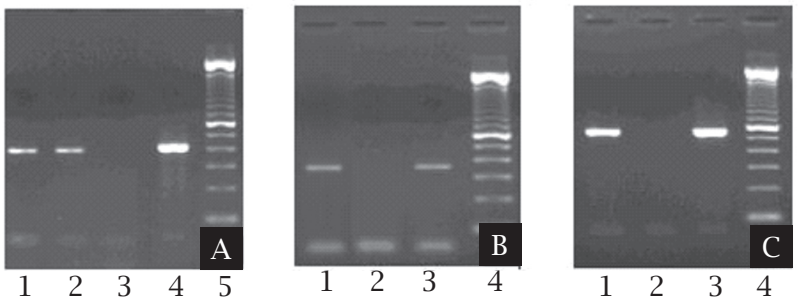

Graphic 1: Frequency of erm genes in S. aureus isolates.

S. aureus

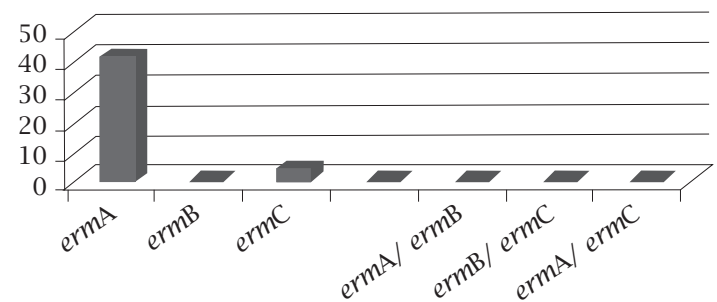

Graphic 2: Frequency of erm genes in SCN isolates.

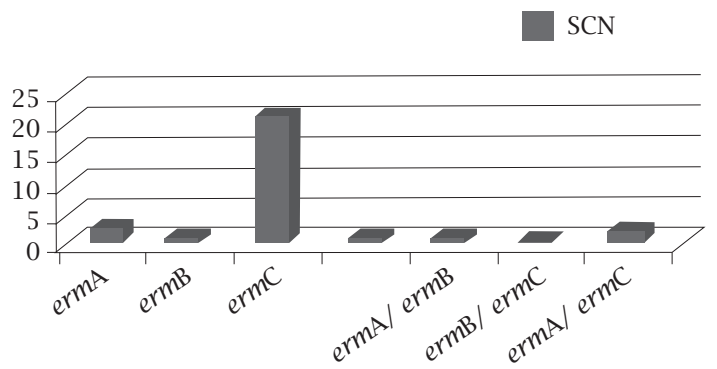

\section{DISCUSSION}

The incidence of constitutive and inducible $\mathrm{MLS}_{\mathrm{B}}$ resistance may vary according to different geographic region and even from hospital to hospital or patient group. This variability is usually associated with the inconsistent use of erythromycin in different institutions; the origin of the isolate (nosocomial versus community acquired); patient age and clinical samples. ${ }^{15,16}$ In our study $53.3 \%$ of staphylococci presented one of three $M_{L} S_{B}$ resistance phenotypes. In fact, $\mathrm{cMLS}_{\mathrm{B}}$ resistance phenotype was the most common $(46.7 \%)$ and $\mathrm{iMLS}_{\mathrm{B}}$ and $\mathrm{MS}_{\mathrm{B}}$ phenotype were each detected in only $3.3 \%$ of the staphylococci.

In a study conduced in Texas by Fiebelkorn et al. the $\mathrm{CMLS}_{\mathrm{B}}$ resistance phenotype was also the most prevalent phenotype (41.7\% of staphylococci) but the iMLS $\mathrm{B}_{B}$ was found in $25.2 \%$ of the isolates, indicating a difference in relation to ${ }_{i M L S}$ data of the present study. ${ }^{10}$ In Europe where the $M_{L} S_{B}$ phenotype prevalence are somehow variable, in London Hamilton-Miller et al. detected staphylococci with iMLS ${ }_{\mathrm{B}}$ as the predominant phenotype ( $43 \%$ of isolates) and the $\mathrm{cMLS}_{\mathrm{B}}$ resistance phenotype was detected in only $24 \%$ of isolates. ${ }^{17}$ The D test is critical, in this scenario, to avoid therapeutic failure. On the other hand, CNS isolates studied in Sevilla demonstrated that the $\mathrm{MS}_{\mathrm{B}}$ resistance phenotype was more common $(11.2 \%)$ in relation to the other phenotypes $\left(\mathrm{iMLS}_{\mathrm{B}}\right.$ 
$7.4 \%$ and $\left.\mathrm{cMLS}_{\mathrm{B}} 3.2 \%\right) .{ }^{16}$ In contrast, the $\mathrm{cMLS}_{\mathrm{B}}$ resistance phenotype was most frequent (46.9\%) as compared to iMLS $_{\mathrm{B}}(30.2 \%)$ in France. ${ }^{14}$

In Turkey it was demonstrated that the prevalence of the $\mathrm{CMLS}_{\mathrm{B}}$ phenotype is higher than that of the $\mathrm{iMLS}_{\mathrm{B}}$ phenotype and the $\mathrm{MS}_{\mathrm{B}}$ phenotype is low, data similar to our study. ${ }^{15,18-20}$

A previous study conducted in our city evaluated 200 CNS and showed that only $2.5 \%$ of isolates presented the iMLS $_{B}$ resistance phenotype. ${ }^{21}$ Therefore, one could speculate that the prevalence of the inducible phenotype is low in our city.

Despite the fact that there is geographic variability among $\mathrm{MLS}_{\mathrm{B}}$ resistance phenotypes, the prevalence of erm genes has been reported to be similar in various countries. According to our findings, the ermA gene was the most prevalent among the S. aureus isolates (43.6\%) and the ermC gene was the most prevalent among the SCN isolates (37.9\%). Only three isolates of staphylococci presented the ermB gene (2.0\%). The presence of more than one erm gene was not detected in S. aureus but it was observed in four SCN isolates. According to Martineau et al., in Canada, $20.9 \%$ of the S. aureus were positive for the ermA gene and $66 \%$ of CNS were positive for the ermC gene, demonstrating that the prevalence of the ermA gene in S. aureus is slightly lower in comparison to other studies. ${ }^{22} \mathrm{~A}$ multicenter study in 24 European university hospitals confirmed the high prevalence of ermA gene and the low prevalence of erm $\mathrm{C}$ and ermB genes among 851 S. aureus. ${ }^{23}$ Lina et al. found $63.2 \%$ of $S$. aureus with ermA gene positive and $44 \%$ of CNS strains erm C gene positive, while the ermB gene was present in only $1 \%$ of staphylococci. ${ }^{14}$ The results reported by Westh et al. in Denmark, also showed a high prevalence of the ermA gene in S. aureus isolates and the ermC gene in CNS strains, as well as a low prevalence for the ermB gene. ${ }^{24}$ In our study, the ermB gene was also detected in a small percentage of staphylococci isolates. This gene is generally found in animal staphylococci strains. ${ }^{6,14,17}$

In the present study, eight isolates (three S. aureus and five SCN) susceptible to erythromycin proved to carry erm genes (seven ermA e one erm C). The presence of erm genes among isolates of staphylococci susceptible to erythromycin had already been demonstrated in another study. ${ }^{22}$ This may be due to the lack of expression of erm genes due to factors which down regulate the expression of this gene. ${ }^{22,23}$

In our study we found six $S$. aureus isolates and one CNS resistant to erythromycin and clindamycin but with negative genotypic test. These results were probably associated with the presence of other genes, such as msrA and $m s r \mathrm{~B}$, with low frequency in Staphylococci species isolated form humans, ${ }^{25}$ which were not evaluated in this study.

We detected three $S$. aureus resistant to clindamycin and susceptible to erythromycin, which did not harbor erm genes. In a study conducted by Lina and et al., the only SCN sample that presented this susceptibility profile was positive for the genes $\operatorname{lin} \mathrm{A}$ and $\operatorname{lin} \mathrm{A}^{\prime} .{ }^{14}$ These genes confer lincosamides resistance only in S. heamolyticus and S. aureus. Incidence of staphylococci with lincosamide resistance but without resistance to macrolides and streptogramins is usually very low. ${ }^{14,26}$

\section{CONCLUSION}

The aim of this study was to determine the prevalence of the $\mathrm{MLS}_{\mathrm{B}}$ phenotypes and genes in Staphylococcus aureus and coagulase-negative staphylococci from patients receiving care at our hospital. We found that constitutive $\mathrm{MLS}_{\mathrm{B}}$ resistance was the most prevalent phenotype in staphylococci; ermA was the most prevalent gene in S. aureus strains, whereas erm $\mathrm{C}$ was the most frequent gene in CNS isolates. Therefore, staphylococci with resistance to $\mathrm{MLS}_{\mathrm{B}}$ are usually detected directly in routine susceptibility test and the "D test" is not required to be performed in most of our isolates. However, other regions in our country may not present the same resistance profile as ours and, therefore, surveillance studies are warranted in different institutions.

\section{REFERENCES}

1. Kloos WE, Bannerman TL. Update on clinical significance of coagulase-negative staphylococci. Clin Microbiol Rev 1994;7:117-140.

2. Pfaller MA, Herwaldt LA. Laboratory clinical and epidemiological aspects of coagulase-negative staphylococci. Clin Microbiol Rev 1988;1:281-299.

3. Rupp ME, Archer GL. Coagulase-negative staphylococci pathogens associated with medical progress. Clin Infect Dis 1994;19:231-245.

4. Leclercq R. Mechanisms of resistance to macrolides and lincosamides: Nature of the resistance elements and their clinical implications. Clin Infect Dis 2002; 34: 482-492.

5. Roberts MC, Sutcliffe J, Courvalin P, Jensen LB, Rood J, Seppala H. Nomenclature for macrolide-lincosamide-streptogramin B resistance determinants. Antimicrob. Agents Chemother 1999; 43:2823-2830.

6. Eady EA, Roos JI, Tipper JL, Walters CE, Cove JH, Noble WC. Distribution of genes encoding erythromycin ribosomal methylases and an erythromycin efflux pump in epidemiologically distinct groups of staphylococci. Antimicrob Agents Chemother 1993;31:211-217.

7. Khan SA, Novick RP. Terminal nucleotide sequences of Tn 551 a transposon specifying erythromycin resistance in Staphylococcus aureus: homology with Tn3. Plasmid 1980; 4:148-154.

8. Rossi F, Andreazzi DB. Interpretando o Antibiograma. Atheneu $1^{\circ}$ Ed, São Paulo 2005, pp 41-43.

9. Weisblum B. Erythromycin resistance by ribosome modification. Antimicrob Agents Chemother 1995;39:577-585.

10. Fiebelkorn KR, Crawford SA, McElmeel ML, Jorensen JH. Practical Disk Diffusion Method for Detection of Inducible Clindamycin Resistance in Staphylococcus aureus and Coagulase Negative Staphylococci. J Clin Microbiol 2003; 41:4740-4744.

11. Clinical and Laboratory Standards Institute. Performance standards for antimicrobial susceptibility testing: seventeenth informational supplement. M100-S16. Wayne: Clinical and Laboratory Standards Institute; 2007. 
12. Sutcliffe J, Grebe T, Tait-Kamradt A, Wondrack L. Detection of Erythromycin-Resistance Determinants by PCR. Antimicrob Agents and Chemother 1996; 40 (11): 2562-2566.

13. York MK, Gibbs L, Chehab F, Brooks GF. Comparison of PCR Detection of mecA with Standard Susceptibility Testing Methods To Determine Methicilin Resistance in Coagulase-Negative Staphylococci. J Clin Microbiol 1996; 34 (2) 249-253.

14. Gerard L, Quaglia A, Reverdy ME, Lequerq R, Vandenesch F, Etienne J. Distribution of Genes Encoding Resistance to Macrolides, Lincosamides, and Streptogramins among Staphylococci. Antimicrob Agents Chemother 1999; 43 (5) 1062 - 1066.

15. Aktas Z, Aridogan A, Kayacan CB, Aydin D. Resistance to Macrolide, Lincosamide and Streptogramin Antibiotics in Staphylococcus Isolated in Istanbul, Turkey. J Microbiol 2007; 45(4): 286-290.

16. Merino-Díaz L, Cantos de la Casa A, Torres-Sanchez MJ, Aznar-Mantin J. Detección de resistencia inducible a clindamicina em aislados cutáneos de Staphylococcus ssp. por métodos fenotípicos y genotípicos. Enferm Infecc Microbiol Clin 2006; 25(2): 77-81.

17. Hamilton-Miller JMT, Shah S. Patterns of phenotypic resistance to the macrolide-lincosamide-ketolide-streptogramin group of antibiotics in staphylococci. J Antimicrob Chemother 2000; 46:941-949.

18. Delialioglu N, Aslan G, Ozturk C, Baki V, Sen S, Emekdas G. Inducible Clindamycin Resistance in Staphylococci Isolate from Clinical Samples. Jnp J Infect Dis 2005; 58:104-106.

19. Saribas Z, Tunckanat F, Pinar A. Prevalence of erm genes encoding macrolide-lincosamide-streptogramin (MLS) resistance among in a Turkish university hospital. Clin Microbiol Infect 2006; 12:797-799.
20. Yialmz G, Aydin K, Iskender S, Caylan R, Koksal I. Detection and prevalence of inducible clindamycin resistance in staphylococci. J Med Microbiol 2007; 56: 342-345.

21. Perez LR, Caierão J, Antunes AL, d'Azevedo PA. Use of the D Test Method to Detect Inducible Clindamycin Resistance in Coagulase Negative Staphylococci (CoNS). Braz J Infect Dis 2007; 11:186-188.

22. Martineau F, Picard F, Lansac N, Ménard C, Roy PH, Ouellette M, Bergeron MG. Correlation between the Resistance Genotype Determined by Multiplex PCR Assays and the Antibiotic Susceptibility Patterns of Staphylococcus aureus an Staphylococcus epidermidis. Antimicrob Agents and Chemother 2000; 44:231-238.

23. Schmitz FJ, Sadurski R, Kray A, Boos M, Geisel M, Köhrer K, Verhoef J, Fluit C. Prevalence of macrolide-resistance genes in Staphylococcus aureus and Enterococcus faecium isolates from 24 European university hospitals. J Antimicrob Chemother 2000; 45: 891-894.

24. Westh H, Hougaard DM, Vuust J, Rosdahl T. Prevalence of erm gene classes in erythromycin-resistance Staphylococcus aureus strains isolated between 1959 and 1988. Antimicrob Agents Chemother 1995; 39:369-373.

25. Chung WO, Werckenthin C, Schwarz S, Roberts MC. Host range of the ermF methylase gene in bacteria of human and animal origin. J Antimicrob Chemother 1999; 43:5-14.

26. Brisson-Noël A, Delrieu P, Samain D, Courvalin P. Inactivation of lincosamide antibiotics in Staphylococcus. Identification of lincosamide o-nucleotidyltransferases and comparison of the corresponding resistance genes. J Biol Chem 1988; 263:1588015887. 